
\title{
28 Research Square \\ Curvularia Lunata as New Causal Pathogen of Tomato Early Blight Disease in Egypt
}

\author{
Heba-Alla S. AbdElatah
}

Assiut Univerisity

Nashwa M.A. Sallam ( $\nabla$ nashwasallam@aun.edu.eg )

Assiut University https://orcid.org/0000-0002-2356-1930

Mohamed S. Mohamed

Assiut Univeristy

Hadeel M. M. Khalil Bagy

Assiut University Faculty of Agriculture

\section{Short Report}

Keywords: Early blight, Alternaria solani, Curvularia lunata, A. alternata, molecular identification (ITS)

Posted Date: February 24th, 2021

DOl: https://doi.org/10.21203/rs.3.rs-234169/v1

License: (c) (i) This work is licensed under a Creative Commons Attribution 4.0 International License. Read Full License

Version of Record: A version of this preprint was published at Molecular Biology Reports on March 9th, 2021. See the published version at https://doi.org/10.1007/s11033-021-06254-8. 


\section{Abstract}

Tomato plants displaying early blight symptoms were collected from different localities in the provinces of Assiut and Sohag, Egypt. The causal pathogens were isolated on potato dextrose agar plates. Pathogenicity tests with 48 isolates were carried out under greenhouse conditions on tomato cultivar (CV 844). All tested isolates caused symptoms of early blight disease with different degrees. The highest disease severity on tomato plants was found after inoculation with isolate No. 6 followed by isolates No. 20 and No. 31. The most pathogenic isolates were identified by sequence analysis using ITS1 and ITS4 primers. The analysis of the amplified sequences from fungal isolates No. 6, 20 and 31 displayed 99 $100 \%$ nucleotide identity with Alternaria solani, Curvularia lunata and A. alternata, respectively. To our knowledge, this is the first report of Curvularia lunata as one of the causal pathogens of early blight disease of tomato plants in Egypt.

\section{Introduction}

Tomato (Solanum lycopersicum L.) is an important horticultural crop and grown worldwide. It is the world's second most consumed vegetable crop after potato [1]. In 2008, Egypt ranked fifth in the world in the production of tomato [2]. In 2018, the cultivated tomato area in Egypt was approximately 175 Thousand hectares, producing about 6.8 Mill. tons of tomatoes [3]. Early blight (EB) is a destructive fungal disease of tomato and potato plants [1, 4]. As the plants get older, the symptoms of EB disease first develop on the lower leaves. They appear as small, dark, necrotic lesions which typically have targetlike concentric circles and are often surrounded by a yellowing zone. The pathogen releases enzymes that degrade the host cell wall, and toxins that destroy the host cells, thereby making nutrients accessible to the pathogen [5]. Under favorable conditions, the disease spreads over all parts of the plant (leaves, stems, branches and fruits), leading to detaching of leaves, drying of branches and premature fruit drop. The resulting fruit yield losses often amount to 50 to $86 \%$ [6-8]. For the development of an effective disease management strategy it is essential to understand the pathogen population. Therefore, efficient and conclusive identification of the inciting pathogens is important $[4,9]$. The previously employed classical methods (mycelial growth rates, colony morphology, microscopic features) to identify fungal species are not as specific as the genotyping methods [10]. Many of the modern identification methods are based on molecular genetic relationships among fungal groups [11]. Molecular techniques are effective instruments for speedy detection of fungal species [12]. Characterization based on sequence analysis of genes of the internal transcribed spacer regions (ITS) of the rDNA is a useful tool to identify and characterize fungal isolates as presumed new species [13-15]. It has generally been found beneficial for research at species level and within species $[15,16]$.

The objective of the present study was to characterize the causal pathogens of tomato early blight disease in Upper Egypt (Provinces Assiut and Sohag). For this purpose, candidate strains were isolated from diseased plants and screened in pathogenicity tests. The most pathogenic isolates were then identified by PCR with ITS primers and sequencing of the PCR products. 


\section{Materials And Methods}

\section{Isolation of pathogens}

Naturally diseased early blight tomato plants were obtained from open fields in various localities in Assiut and Sohag. Diseased leaves were cut into small pieces, put in $0.5 \%$ sodium hypochlorite for 2 min. and then rinsed 3 times in sterilized distilled water for $2 \mathrm{~min}$. to eliminate residues of the disinfectant. The leaf parts were placed on potato dextrose agar (PDA) in $9 \mathrm{~cm}$ Petri plates, and the plates were incubated at $27 \pm 1{ }^{\circ} \mathrm{C}$ for 4 days. After the incubation period, tips of outgrowing hyphae were singly picked from the lesions and transferred to PDA plates. The plates were incubated at $27 \pm 1{ }^{\circ} \mathrm{C}$ for 15 days [4]. Isolates were held at $4{ }^{\circ} \mathrm{C}$ on a PDA medium until used.

\section{Pathogenicity tests}

Pathogenicity tests were carried out under greenhouse conditions at the Department of Plant Pathology, Faculty of Agriculture, Assiut University. Thirty day-old tomato seedlings (cv 844) were replanted in sterilized pots (30 cm diameter) filled with autoclaved sandy clay soil ( $3 \mathrm{~kg} / \mathrm{pot}$; two seedlings / pot), and $3 \mathrm{~g}$ fertilizer NPK 12:4:6 were added to each pot. The pots were kept at $30 \pm 5{ }^{\circ} \mathrm{C}$ with $68-80 \%$ relative humidity and watered whenever needed [4]. Altogether, 48 isolates from diseased tomato leaves were employed in the pathogenicity test. To sporulating cultures on PDA, obtained after incubation at 27 $\pm 1^{\circ} \mathrm{C}$ as described above, distilled water was added at $10 \mathrm{ml}$ per plate, and the cultures were gently rubbed with a sterile needle. The resulting spore suspensions were adjusted to $4 \times 10^{6} \mathrm{CFU} / \mathrm{ml}$ and sprayed on 30-day old tomato plants using an atomizer. Control plants were sprayed with water [17]. The plants were then covered for 48 hours with polythene bags. Each treatment had three replicates, each with three pots. Thirty days after inoculation the disease severity was rated numerically using a 0 - 4 scale $[7,9]$, with $0=$ leaves without any spot (controls), $1=$ spots occupying $<25 \%, 2=26-50 \%, 3=51$ $75 \%$, and $4=76-100 \%$ of the leaf area. The formula was then modified as follows: Disease severity (\%) $=\Sigma(n \times r) / N R \times 100$, where $n=$ number of infected leaves on the plant, $r=$ numerical rate of infected leaves, $\mathrm{N}=$ total number of leaves on the plant and $\mathrm{R}=$ maximum numeric rate.

In order to fulfill Koch`s postulates, the pathogens were re-isolated from tomato plants showing the typical symptoms of early blight and compared by microscopy to the material used for inoculation.

\section{Molecular characterization of pathogenic isolates}

The three fungal isolates causing the highest disease severity of early blight disease were identified using molecular methods (ITS-rDNA). The isolates were cultured for 7 days at $27{ }^{\circ} \mathrm{C}$ on Czapek`s yeast extract agar with 20\% sucrose (CY20S) [18] and sent to Biology Research Unit, Assiut University for DNA extraction using the Patho gene-spin ${ }^{\mathrm{TM}}$ DNA / RNA extraction kit (Intron Biotechnology, Inc., South Korea). For polymerase chain reaction (PCR) and gene sequencing, extracted DNA was sent to SolGent Co., Ltd., Daejeon, South Korea. The PCR was conducted using two universal fungal primers ITS1 (forward) and ITS4 (reverse) which were integrated in the reaction mixture. Primers are composed according to the 
following, ITS1 (5' - TCC GTA GGT GAA CCT GCG G - 3') and ITS4 (5'- TCC TCC GCT TAT TGA TAT GC -3') [11]. Using a size nucleotide marker (100 base pairs), the purified PCR products were reconfirmed by electrophoreses on $1 \%$ agarose gel. The bands were eluted and sequenced with the incorporation of dideoxynucleotides (dd NTPs). Each sample was sequenced using ITS1 and ITS4 primers in the sense and antisense directions. DNA sequences of the three isolates were assembled using the DNA STAR computer package (version 5.05). Assembled sequences were aligned with those downloaded from GenBank using MAFFT [19]. Alignment gaps and parsimony uninformative characters were treated by BMGE [20]. Maximum-likelihood (ML) and Maximum parsimony (MP) phylogenetic analyses were performed using PhyML 3.0 [21]. The robustness of the most parsimonious trees was evaluated by 1000 bootstrap replications [22]. The best optimal model of nucleotide substitution for the ML analyses was determined using Smart Model Selection (SMS) version 1.8.1 [23]. The phylogenetic tree was visualized using Fig Tree version 1.4.3 [24].

\section{Statistical analysis}

Statistical variance (ANOVA) of data was performed using MSTAT-C program version 2.10 (1991). According to the procedures described by Gomez et al. [25] means were compared by Duncan's multiple range tests and statistical significance was determined at $5 \%$ level.

\section{Results}

\section{Pathogenicity tests}

With 48 fungal isolates, pathogenicity tests were carried out under greenhouse conditions (Table 1). All tested isolates were pathogenic and caused symptoms of early blight disease on tomato plants, although with different degrees. About $75 \%$ of isolates were either highly or very highly pathogenic, whereas the remaining isolates were only low or medium in pathogenicity (Table 2). The highly pathogenic isolates constituted the largest group. Isolates No. 6, 20 and 31 caused the highest disease severity (88-90\%). The symptoms of early blight disease were large spots (dark necrotic lesions, often surrounded by a yellowing zone) which spread over most parts of the plant (Fig.1). The spots coalesced and enlarged over time.

\section{Identification of pathogenic isolates using ITS}

Isolates No. 6, 20 and 31, that among the 48 isolates tested had shown the strongest pathogenicity on tomato plants, were selected for molecular identification using ITS-rDNA sequencing. The resulting sequences were compared using the BLAST program to those of the NCBI site. A $556 \mathrm{bp}$ fragment from isolate No. 6 (synonym: strain AUMC 14485) showed 99\% sequence similarity with four reference strains of Alternaria solani. Based on this, the isolate was identified as A. solani (Fig. 2). The ITS-rDNA sequence of $A$. solani strain AUMC 14485 was deposited in the GenBank under the accession number MT444991. Isolate No. 31 (synonym: strain AUMC 14486) was identified as Alternaria alternata, as sequencing of a $545 \mathrm{bp}$ fragment from this isolate revealed $100 \%$ identity with three reference strains of $A$. alternata (Fig. 2). The ITS-rDNA sequence of $A$. alternata AUMC 14486 was deposited in the GenBank nucleotide 
sequence database under accession number MT777510. The sequencing data of a $562 \mathrm{bp}$ fragment from isolate No. 20 (synonym: strain AUMC 14229) clustered together (100\% identity) with three reference strains of Curvularia lunata (Fig. 2). The isolate was thus named as C. lunata AUMC 14229 and registered in GenBank under the accession number MT444990.

\section{Discussion}

The objective of this study was to obtain information on the fungal pathogens causing early blight of tomato in Upper Egypt. Among the isolates studied, a large variability of the pathogenicity was observed. However, most isolates were grouped as highly or very highly pathogenic. In studies with different isolates of Alternaria, Remezani et al. [26] also observed that all isolates obtained from tomato early blight lesions were pathogenic, with substantial variations in pathogenicity levels between the isolates. Our observations on the disease symptoms incited by inoculation with the pathogenic strains are in agreement with the literature, both regarding shape and color as well as their first appearance on the lower leaves and spreading with increasing growth of plants [27]. A. solani and A. alternata $[1,4]$ as well as a number of other species of Alternaria $[5,28]$ are well known as causal pathogens of early blight of tomato. Curvularia spicifera has been described as a pathogen causing leaf spot of tomato in India [29]. Curvularia lunata was reported to cause fruit rot of tomato [30], but little is known about $C$. lunata as causal pathogen of tomato EB. We are only aware of a single report from Pakistan [31] describing the isolation of $C$. lunata var. aeria from tomato leaves with EB. According to the Index Fungorum [32] $C$. lunata var. aeria is synonym with $C$. Iunata.

To summarize, fungal isolates from diseased tomato plants from Assiut and Sohag (Upper Egypt) were tested for ability to cause tomato EB. Using PCR with ITS primers and sequencing of the PCR products, the three most pathogenic of these isolates were identified as A. solani, A. alternata and C. solani, respectively. While species of Alternaria have been reported before as EB pathogens in Egypt [4], this is the first report for $C$. lunata as causal pathogen EB of tomato in Egypt.

\section{Declarations}

\section{Acknowledgments}

The authors wish to thank Ameer E. Elfarash, Genetics Dept., Fac. Agric., Assiut Univ., Assiut, Egypt and Prof. Dr. Deng X J Department of Plant Protection, College of Agriculture, Yangtze University, Jingzhou, China for discussing the results of this study. This work was supported and funded by Assiut University.

Compliance with ethical standards

Ethical responsibility: Our manuscript is original research and it is not submitted to full or in parts to other journal for publication.

Conflict of interest: The authors declare that they do not have any actual or potential conflict of interest. 
Informed consent: All authors have reviewed the manuscript and approved the final version of manuscript before submission.

\section{AUTHOR CONTRIBUTIONS}

S.N.M.A., and M.S.M. suggested the idea of the work and contributed to data curation and their validation as well as writing original draft. A.H.A.S. and B.H.M.K contributed to the formal analysis of the data S.N.M.A., A.H.A.S and B.H.M.K. contributed to the reviewing and editing the manuscript. All authors reviewed and approved the final version of the manuscript.

\section{References}

[1] Adhikari P, Oh Y, Panthee D R (2017) Current status of early blight resistance in tomato. An update, Inter. J. Molecular. Scien 18:1-12. https://doi.org/10.3390/ijms18102019

[2] Peralta IE, Spooner DM, Knapp S (2008) Taxonomy of wild tomatoes and their relatives (Solanum sections Lycopersicoides, Juglandifolia, Lycopersicon; Solanaceae). Syst Bot Monogr 84:1-186. https://www.cabdirect.org/cabdirect/abstract/20103064022

[3] Food and Agriculture Organization of United Nation (FAO). FAOSTAT, Crops, 2018. Available at http://fenix.fao.org/faostat/beta/en/\#data/QC

[4] Sallam NMA, Abo-Elyousr K AM ( 2012) Blight disease of tomato plants under greenhouse and field conditions. Plant Protect Sci 48(2): 75-80. https://doi.org/10.17221/14/2011-PPS

[5] Rotem J (1994). The genus Alternaria: biology, epidemiology, and pathogenicity, 1st edn. APS St. Paul MN 48- 203 pp. ISBN: 0890541523

[6] Upadhyay SK, Singh, DP, Saikia, R (2009) Genetic diversity of plant growth promoting Rhizobacteria isolated from rhizospheric soil of wheat under saline condition. Cur Microbiol 59: 489-96. https://doi.org/10.1007/s00284-009-9464-1

[7] Sallam NMA (2011) Control of tomato early blight disease by certain aqueous plant extracts. Plant Pathol J 10(4): 187-191. DOI: 10.3923/ppj.2011.187.191

[8] Yadav OP, Dabbas MR, Gaur LB (2014) Screening of tomato advanced lines, genotypes against Alternaria solani. Plant Arch 14: 553-555. http://plantarchives.org/PDF/Vol.\%2014(1)\%20(553-555)

[9] Zheng HH, Zhao J, Wang TY, Wu X H (2015) Characterization of Alternaria species associated with potato foliar diseases in China. Plant Pathol 64: 425-433. https://doi.org/10.1111/ppa.12274

[10] Shahid M, Singh A, Srivastava M, Srivastava D K (2014) Molecular characterization of Trichoderma viride isolated from rhizospheric soils of Uttar Pradesh based on rDNA markers and analysis of their PCRISSR profiles. Molec Biomar Diagn 5:2. http://10.4172/2155-9929.1000170 
[11] White, T. J., Bruns, T., Lee, S., Taylor, J., 1990. Amplification and direct sequencing of fungal ribosomal RNA genes for phylogenetics. In PCR Protocols, A guide to Methods and Applications (ed. M. A. Innis, D. H. Gelfand, J. J. Sninsky\& T. J. White), Academic Press, San Diego, U.S.A. pp. 315-322. http://dx.doi.org/10.1016/b978-0-12-372180-8.50042-1.

[12] Chaerani R, Smulders M, Linden C, Vosman B, Stam P, Voorrips R (2007) QTL identification for early blight resistance (Alternaria solani) in a Solanum lycopersicum $\times$ S. arcanum cross. TAG Theor Appl Genet 114: 439-450. https://doi.org/10.1007/s00122-006-0442-8

[13] Druzhinina I, Kopchinskiy A, Komoń M (2005) An oligonucleotide barcode for species -identification in Trichoderma and Hypocrea. Fung Genet Biol 42: 813-828. https://doi.org/10.1016/j.fgb.2005.06.007

[14] Kubicek, C, Komon-Zelazowska, M, Druzhinina, I (2008) Fungal genus Hypocrea/Trichoderma, from barcodes to biodiversity. J Zhej Univ Scien B 9,753-763.

https://link.springer.com/article/10.1631\%2Fjzus.B0860015

[15] Sallam NMA, Eraky AMI, Sallam A (2019) Effect of Trichoderma spp. on Fusarium wilt disease of tomato. Mol Biol Rep 46: 4463-4470. https://doi.org/10.1007/s11033-019-04901-9

[16] Shahid M, Srivastava M, Sharma A, Singh A, Pandey S, Kumar V, Pathak N, Rastogi S (2013) Molecular characterization of Trichoderma longibrachiatum 21PP isolated from rhizospheric soil based on universal ITS primers. Afric J Microbiol Rese 7: 4902-4906. https://doi.org/10.5897/AJMR2013.5761

[17] Kumar V, Biswas SK, Chowdary VT, Kishan L, Naresh P (2017) Induced synthesis of defense enzymes during induced resistance against early blight of potato using plant extracts as inducer. J Scien Res Rep 16:1-11. ISSN: 2320-0227

[18] Pitt Jl, Hocking AD (2009) Fungi and food spoilage, $3^{\text {rd }}$ edition. Springer Science + Business media LLC, (519 pages). https://www.springer.com/gp/book/9780387922065

[19] Katoh, K, Standley DM (2013) MAFFT multiple sequence alignment software version 7: improvements in performance and usability. Molecular biology and evolution 30, 772-780. https:// doi.org $/ 10.1093 / \mathrm{molbev} / \mathrm{mst010}$

[20] Criscuolo A, Gribaldo S (2010) BMGE (Block Mapping and Gathering with Entropy): a new software for selection of phylogenetic informative regions from multiple sequence alignments. BMC evolutionary biology 10: 210. https://doi.org/10.1186/1471-2148-10-210

[21] Guindon S, Dufayard JF, Lefort V, Anisimova M, Hordijk W, Gascuel O (2010) New algorithms and methods to estimate maximum-likelihood phylogenies: assessing the performance of Phy ML 3.0. Systematic biology 59: 307-321. https://doi.org/10.1093/sysbio/syq010 
[22] Felsenstein, J (1985) Confidence limits on phylogenies: an approach using the bootstrap. Evolution 39, 783-791. https://www.jstor.org/stable/2408678

[23] Lefort V, Longueville, JE, Gascuel O (2017) SMS: smart model selection in PhyML. Molecular biology and evolution 34: 2422-2424. https://doi.org/10.1093/molbev/msx149

[24] Rambaut A, Drummond, A (2012) Fig Tree version 1.4.0. htt://tree.bio.ed.ac.uk/software/figtree

[25] Gomez KA, Gomez AA, Gomez KA (1984) Statistical procedures for agricultural research. Wiley. ISBN: 978-0-471-87092-0

[25] Ryan KJ, Ray CG, Sherris JC (2004) Medical microbiology: An introduction to infectious diseases. 4th Edn., McGraw Hill, New York, USA., Pages: 979. ISBN-13: 9780838585290.

[26] Ramezani, Y, Taheri, P, Mamarabadi, M, (2019) Identification of Alternaria spp. associated with tomato early blight in Iran and investigating some of their virulence factors. J Plant Pathol 101, 647-659. https://link.springer.com/article/10.1007\%2Fs42161-019-00259-w

[27] Singh C P, Kumar R, Singh M, Rai A., Singh M C, Rai M (2011) Identification of resistant sources against early blight disease of tomato. Indian J Hort 68(4): 516-521.

https://www.researchgate.net/publication/260991904

[28] Kokaeva LY, Belosokhov AF, Doeva LY, Skolotneva ES, Elansky SN (2018) Distribution of Alternaria species on blighted potato and tomato leaves in Russia. J Plant Dis Prot 125: 205-212.

https://doi.org/10.1007/s41348-017-0135-3

[29] Rao Y H, Devi PS, Vemavarapu V V. Chowdary K R (2020) In vitro Evaluation of Antagonistic Potential of Native Trichoderma spp., Botanicals and Fungicides against Curvularia spicifera causing Curvularia Leaf Spot of Tomato in Manipur. Int J Curr Microbiol App Sci 9(10): 1815-1823.

https://doi.org/10.20546/ijcmas.2020.910.221

[30] Fajola AO (1979). The post-harvest fruit rots of tomato (Lycopersicum esculentum) in Nigeria. Food/Nahrung. 23(2): 105-109. https://doi.org/10.1002/food.19790230202

[31] Iftikhar S, Shahid A A, Nawaz K, Ali S W (2016) First report of Curvularia lunata var. aeria causing leaf blight on tomato in Pakistan. J Plant Pathol 98: 171-185. http://dx.doi.org/10.4454/JPP.V9811.063

[32] Index Fungorum. Accessed Febr. $2^{\text {nd }} 2021$.

http://www.speciesfungorum.org/Names/SynSpecies.asp?RecordID=269889

\section{Tables}

Table1: Pathogenicity tests of 48 fungal isolates on tomato cultivar (CV 844) under greenhouse conditions. 


\begin{tabular}{|llllll|}
\hline Isolates No. & Disease severity \% & Lacation & Isolates No. & Disease severity \% & Lacation \\
\hline 1 & $30.76 \pm 0.08 \mathrm{t}$ & Assiut & 25 & $65.00 \pm 0.64 \mathrm{jk}$ & Sohag \\
2 & $30.15 \pm 0.21 \mathrm{t}$ & Sohag & 26 & $34.26 \pm 0.66 \mathrm{~s}$ & Sohag \\
3 & $70.06 \pm 0.06 \mathrm{~h}$ & Sohag & 27 & $60.89 \mathrm{I} \pm 0.57 \mathrm{~m}$ & Sohag \\
4 & $41.79 \pm 1.26 \mathrm{r}$ & Sohag & 28 & $62.85 \pm 1.29 \mathrm{kl}$ & Sohag \\
5 & $58.02 \pm 1.50 \mathrm{n}$ & Sohag & 29 & $76.29 \pm 0.74 \mathrm{fg}$ & Assiut \\
6 & $94.04 \pm 1.12 \mathrm{a}$ & Assiut & 30 & $70.20 \pm 0.07 \mathrm{~h}$ & Assiut \\
7 & $59.47 \pm 0.57 \mathrm{mn}$ & Assiut & 31 & $87.98 \mathrm{~b} \pm 1.08 \mathrm{c}$ & Assiut \\
8 & $51.73 \pm 0.46 \mathrm{op}$ & Assiut & 32 & $32.18 \pm 1.69 \mathrm{st}$ & Assiut \\
9 & $39.50 \pm 0.67 \mathrm{r}$ & Assiut & 33 & $80.26 \pm 0.09 \mathrm{de}$ & Assiut \\
10 & $60.28 \pm \pm 0.15 \mathrm{mn}$ & Assiut & 34 & $80.00 \pm 0.69 \mathrm{de}$ & Assiut \\
11 & $30.50 \pm 0.21 \mathrm{t}$ & Sohag & 35 & $66.67 \pm 0.93 \mathrm{ij}$ & Sohag \\
12 & $50.52 \pm 0.36 \mathrm{p}$ & Sohag & 36 & $30.39 \pm 0.01 \mathrm{t}$ & Sohag \\
13 & $42.20 \pm 1.13 \mathrm{qr}$ & Sohag & 37 & $44.59 \pm 0.58 \mathrm{q}$ & Sohag \\
14 & $51.07 \pm 0.63 \mathrm{p}$ & Sohag & 38 & $54.29 \pm 0.50 \mathrm{o}$ & Sohag \\
15 & $50.52 \pm 0.29 \mathrm{p}$ & Sohag & 39 & $76.36 \pm 1.08 \mathrm{fg}$ & Sohag \\
16 & $40.26 \pm 0.21 \mathrm{r}$ & Sohag & 40 & $66.96 \pm 1.19 \mathrm{ij}$ & Sohag \\
17 & $69.00 \pm 1.23 \mathrm{hi}$ & Sohag & 41 & $84.33 \pm 0.42 \mathrm{c}$ & Sohag \\
18 & $65.11 \pm 0.86 \mathrm{jk}$ & Sohag & 42 & $59.89 \pm 0.17 \mathrm{mn}$ & Sohag \\
19 & $32.07 \pm 0.81 \mathrm{st}$ & Sohag & 43 & $74.26 \pm 1.66 \mathrm{~g}$ & Assiut \\
20 & $90.04 \pm 1.06 \mathrm{~b}$ & Sohag & 44 & $61.39 \pm 0.84 \mathrm{Im}$ & Assiut \\
21 & $31.26 \pm 0.88 \mathrm{t}$ & Sohag & 45 & $82.43 \pm 1.43 \mathrm{~cd}$ & Assiut \\
22 & $54.27 \pm 2.14 \mathrm{o}$ & Assiut & 46 & $78.34 \pm 0.12 \mathrm{ef}$ & Assiut \\
23 & $62.28 \pm 1.26 \mathrm{Im}$ & Assiut & 47 & $70.96 \pm 0.35 \mathrm{~h}$ & Assiut \\
24 & $30.55 \pm 0.75 \mathrm{t}$ & Assiut & 48 & $67 \pm 1.67 \mathrm{u}$ & - \\
\hline
\end{tabular}

Means defined in columns with the same letter(s) do not significantly according to the multiple range check by Duncan $(P=0.05)$. All values are the means of three replicates $\pm S E$ 
Table 2: Grouping of isolates according to their ability to cause symptoms of early blight

\begin{tabular}{|ll|}
\hline Pathogenicity group (disease severity) & Number of isolates $(n=48)$ \\
\hline Low $(10-35 \%)$ & 8 \\
\hline Medium $(36-50 \%)$ & 5 \\
\hline High $(51-69 \%)$ & 21 \\
\hline Very high $(70-100 \%)$ & 14 \\
\hline
\end{tabular}

Figures 

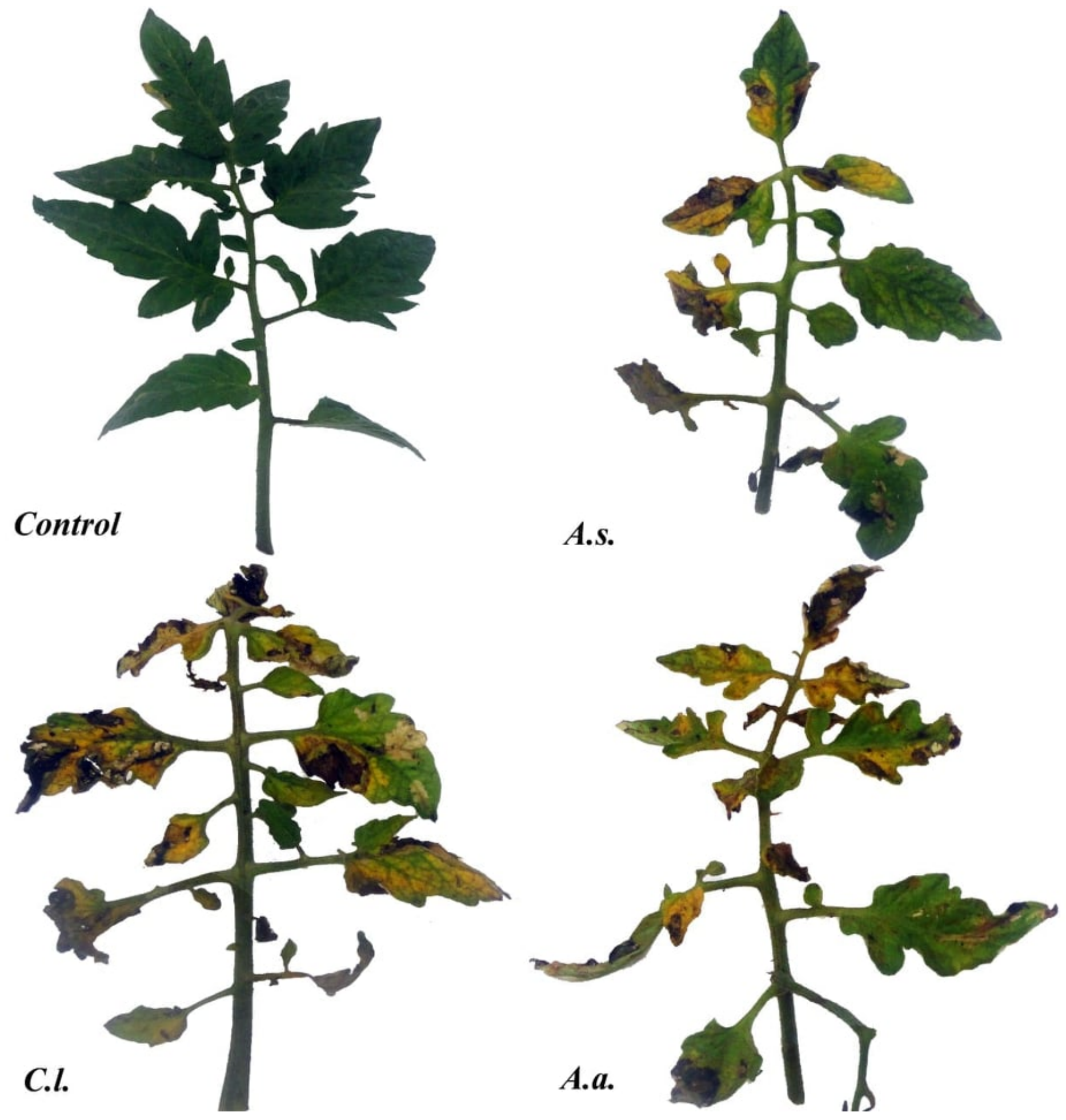

Figure 1

Symptoms of early blight disease on tomato leaves caused by Altrnaria solani (A.S.), Clvularia lunata (C.L.) and Altrnaria alternata (A.a.). Healthy plants (control) haven't any symptoms of the disease. 


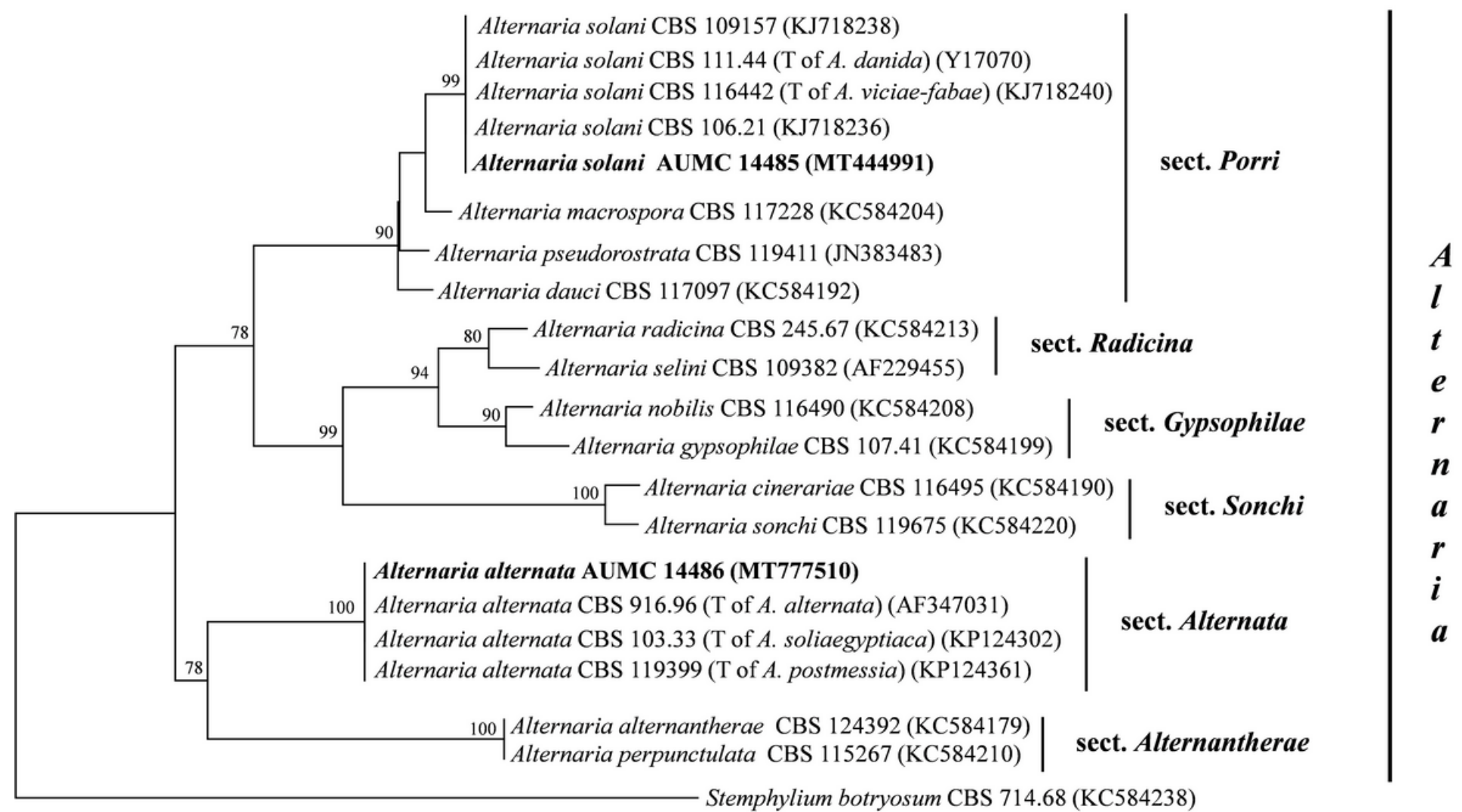

Stemphylium botryosum CBS 714.68 (KC584238)

0.01

Figure 2

Maximum likelihood phylogenetic tree based ITS sequences and bootstrap support values $>60$ (BS) are given at the nodes (BS). ITS sequences of rDNA of the isolated fungal strains (No. 6 and 31) in the present study were Alternaria solani (AUMC 14485) and Alternaria alternata (AUMC 14486) resp. which were aligned with closely related sequences accessed from the GenBank. The marker reflects the relative phylogenetic distance measurement. 


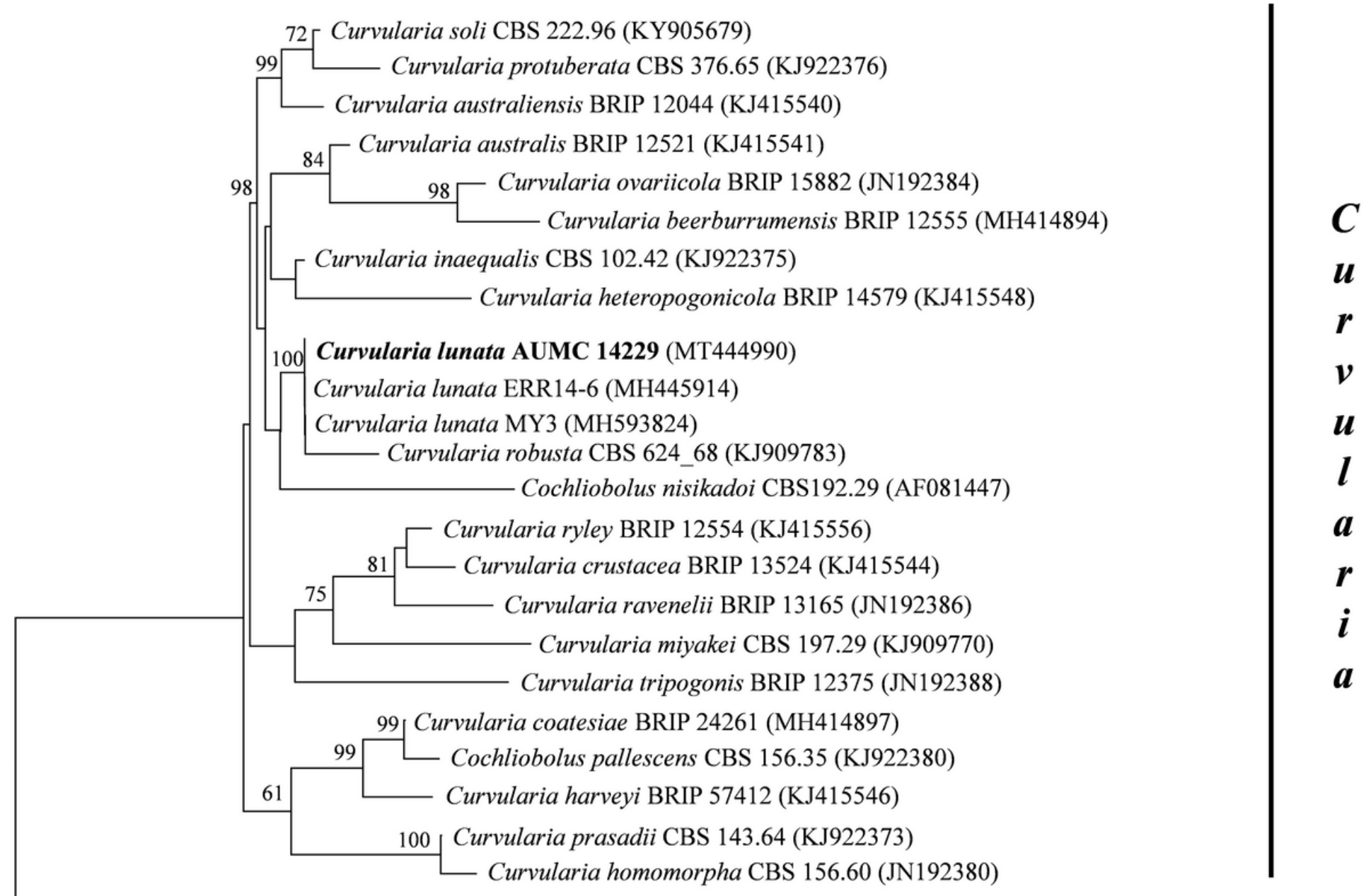

Alternaria alternata CBS 119399 (KP124361)

0.01

Figure 3

Maximum likelihood phylogenetic tree based ITS sequences and bootstrap support values $>60$ (BS) are given at the nodes (BS) on ITS sequences of rDNA of the isolated fungal strain (No. 20) in the present study was Curvularia lunata (AUMC 14229) aligned with closely related sequences accessed from the Gen Bank. The marker reflects the relative phylogenetic distance measurement 